one of his tempers to know whether Crowe could not or would not hear him.

It was natural that Bragg should turn to Crowe for help in the preparation of his own Royal Institution lectures when he succeeded Rutherford in the Cavendish chair. These lectures were distinguished by a quite exceptional clarity and thoroughness of preparation and owed a great deal to Crowe's patience and skill in mastering extremely ingenious and delicate techniques. It was not only in this work, however, that Bragg found Crowe's practical skill a match for his own inventiveness. They worked together during the Second World War, and almost immediately afterwards Crowe ventured into a new field, assembling and operating the first electron microscope in the Laboratory, one of the first in the country. Even Crowe's temperament was stretched to the limit by this wayward instrument and he always maintained it was during this period he learnt to swear "aloud". Nevertheless, Bragg's wisdom in setting Crowe to the task bore rich dividends in Crowe's contributions to the technique of preparing specimen replicas.

In the Cavendish, Crowe was respected for what he could do and well liked for what he was. In experimental physics his death marks the end of an era. No one now in pursuit of the highest prizes plays with wax or bothers to split mica. Yet these trivialities played a not negligible part in an intellectual revolution. It is right that the man who could do them and did them should be remembered.

\section{Prof. J. M. Mackintosh}

Prof. J. M. Mackintosh died at his home in Bristol on April 20, at the age of 75. In his lifetime he spanned almost the whole of our experience of public health, first as County Medical Officer of Northamptonshire, then as Chief Medical Officer of the Department of Health for Scotland, professor of public health at Glasgow, and as dean and professor of public health at the London School of Hygiene and Tropical Medicine. A highlander by origin and temperament, he was born in Kilmarnock where his father practised as a solicitor, and educated at Glasgow High School and University. He was a graduate in arts and medicine in the older Scottish tradition of the educated doctor: at the University of Glasgow he was one of a vintage generation whose studies were interrupted by active service in the First World War. Severely wounded as a subaltern in the Cameron. Highlanders, he was sent home and finished his medical studies. He returned to the war as a medical officer in the R.A.M.C. It was war-time service which determined his choice of public health as a career.

After service as an assistant medical officer in Dorset, Burton-on-Trent, and Leicestershire he was appointed County Medical Officer of Northamptonshire in 1930. There he made a celebrated series of surveys of rural housing, and his reports, illustrated with his own pen-andink sketches, are a unique piece of English social history. He loved his period of public health service.

From 1937 until 1941 he served as Chief Medical Officer of Scotlend. This was a period when attention had turned in Scotland to the need for major reform of the health services, and a period of hectic planning in anticipation of war. This experience was formative of his thinking about hospital planning and strategy. At this time, too, James Mackintosh discovered with a special delight and appreciation the Highlands and Islands Medical Service which had pioneered the provision of health services for remote and scattered populations; in retirement it was one of his unrealized hopes that he might be able to write a history of the service.

In 1941 he resigned from central government work, which he had felt restricting and lacking in those individual contacts whose stimulus he found rewarding. He moved to the chair of public health of the University of Glasgow and began the academic career by means of which his name has become widely known. 'To begin with, however, he was still concerned with war and was moved to the United States to advise on the medical aspects of civil defence. This was the beginning of an association with American colleagues which continued for the rest of his life. In 1944 James Mackintosh was appointed dean and professor of public health at the London School of Hygiene and Tropical Medicine and continued there until his retirement in 1956. The end of the war was a time of ferment. Young men out of the forces were eager to make their mark in their country's health services. Inereasingly, postgraduate students came to learn from British experience and teaching. The times welcomed the gifts of James Mackintosh as a thinker and teacher. His lectures on the history and development of health services were a delight, tantalizing to those who wanted a text-book exposition, but profoundly educative in giving a sense of historical perspective and the development of health services as a function of contemporary culture and thought. Mackintosh was beyond all else a social philosopher of the health services, weaving his text from wide reading and experience, and illuminating generalizations from the particular example with a special skill of his own.

When he retired from his chair in 1956 he was already frail and in poor health. He nevertheless had two further successful careers before he died. He worked in Geneva as a consultant to the World Health Organization, and was largely responsible for the production of its First Report on the World Health Situation, a classic of its kind. $\mathrm{He}$ later worked in the United States for the American Hospital Association and the Milbank Foundation, and his volume of essays on Topics in Public Health published last year was partly produced at that time.

\section{J. H. F. BROTHERSTON}

\section{Dr. A. C. Stephen}

Dr. Alexander (Alastair) Charles Stephen, who was keeper of the Department of Natural History in the Royal Scottish Museum from 1935 until 1958, died suddenly at his home in Edinburgh on. June 3 at the age of seventy-two.

Born at Garvock, Kincardineshire, he was educated at Robert Gordon's College and Marischal College, Aberdeen. His academic course was interrupted by service in France and Belgium, but he graduated at Aberdeen in 1919. His first appointment was junior naturalist on the scientific staff of the Fisheries Board for Scotland in 1920, where he was responsible for an investigation into the distribution of animal life on the bottom of the North Sea and adjoining areas.

He joined the Royal Scottish Museum in June 1925 as assistant in the Department of Natural History, and his period of service was notable for the opening of new halls and galleries which, in their presentation of material, were well in advance of other museums in Britain. He continued his research in marine zoology and was the first to apply techniques for quantitative study to the intertidal fauna of sandy and silty shores-work which yielded valuable information on the ecology of these zones and formed his thesis for the D.Sc. in 1934. He wrote on the distribution of cephalopods in British waters and was an authority on the taxonomy of echiurids, sipunculids and priapulids, publishing several reports on material from Africa collected during the Discovery and John Murray Expeditions, and from the B.A.N.Z.A.R. Expeditions. He completed a synopsis of the British specics and, at the time of his death, was engaged in the preparation of a monograph of the world species.

For many years he was editor of the Scottish Naturalist, and he served also as president of the Royal Physical Society of Edinburgh and the Astronomical Socioty of Edinburgh. He was also a Fellow of the Royal Society of Edinburgh.

A. Rodger Waterston 